\title{
PENGEMBANGAN MODUL ELEKTRONIK FISIKA BERBASIS I-SETS BERBANTUAN ARTICULATE STORYLINE PADA MATERI GELOMBANG CAHAYA
}

\author{
Siti Fatimah $^{\text {a) }}$, Vina Serevina ${ }^{\text {b) }}$, Sunaryo $^{\text {c) }}$ \\ Prodi Pendidikan Fisika Fakultas Matematika dan Ilmu Pengetahuan Alam, Universitas Negeri Jakarta, Jl. \\ Rawamangun Muka No.1, Kota Jakarta Timur, DKI Jakarta (13220), Indonesia \\ Email: ${ }^{\text {a) }}$ sitifatimah0698@gmail.com, ${ }^{\text {b) }}$ vina_serevina77@yahoo.com, ${ }^{\text {c) }}$ naryounj@yahoo.com
}

\begin{abstract}
Abstrak
Penelitian ini bertujuan mengembangkan modul elektronik fisika berbasis I-SETS berbantuan Articulate Storyline pada materi gelombang cahaya. Penelitian dilakukan kepada peserta didik kelas $\mathrm{X}$ SMAIT/MA. Metode yang digunakan adalah metode research and development (R\&D) dengan model pengembangan ADDIE. Model pengembangan ADDIE meliputi lima tahapan, yaitu tahap analisis (Analyze), tahap perencanaan (Design), tahap pengembangan (Development), tahap implementasi (Implementation), dan tahap evaluasi (Evaluate). Penelitian analisis kebutuhan diintrepretasikan dengan Skala Guttman dengan tipe jawaban "ya-tidak". Berdasarkan hasil analisis kebutuhan yang dilakukan kepada 32 peserta didik dan guru SMAIT/MA Jabodetabek pada Febuari 2020, didapatkan bahwa 100\% membutuhkan bahan ajar alternatif dalam proses pembelajaran khususnya pada materi gelombang cahaya, 56,25\% pembelajaran menggunakan modul elektronik lebih berkualitas dibandingkan pembelajaran tanpa menggunakan modul eletronik, 68,75\% antusias saat mengikuti pembelajaran ISETS pada materi gelombang cahaya, 96,88\% modul elektronik lebih menarik jika dilengkapi dengan data dan fenomena dalam kehidupan sehari-hari yang dikaitkan dengan I-SETS, dan 90,63\% setuju dengan adanya penelitian pengembangan modul elektronik fisika berbasis I-SETS berbantuan Articulate Storyline pada materi gelombang cahaya. Berdasarkan analisis kebutuhan tersebut dapat dinyatakan bahwa dibutuhkan pengembangan modul elektronik fisika berbasis I-SETS berbantuan Articulate Storyline pada materi gelombang cahaya.
\end{abstract}

Kata-kata kunci: Modul elektronik, Gelombang cahaya, I-SETS, Articulate Storyline

\begin{abstract}
The study aims to develop the e-SETS-based physics electronic module with Articulate Storyline on light wave material. This study was conducted to the students of class X SMAIT/MA. The method used in this research is the research and development (R\&D) method with the ADDIE development model. The ADDIE development Model includes five stages, namely the analysis Stage (Analyze), the planning stage (Design), the development phase (Development), the implementation phase (implementation), and the evaluation phase (Evaluate). Research analysis needs to be interpreted with a Guttman scale with a "yes-no" answer type. Based on the results of the analysis of the needs of the 32 students and teachers SMAIT/MA Jabodetabek on Febuari 2020, obtained that $100 \%$ need an alternative teaching materials in the learning process especially on light wave material, $56.25 \%$ of learning using electronic modules is
\end{abstract}


more quality than learning without using the Eletronik module, $68.75 \%$ enthusiastic when following ISETS learning on light wave material, $96.88 \%$ of electronic modules are more attractive if supplemented with data and phenomena in everyday life associated with I-SETS, and $90.63 \%$ agreed with the development of electronic module-based physics I-SETS assisted by Articulate Storyline in light wave material. Based on these needs analysis, it can be stated that it needed the development of electronic modules physics-based I-SETS assisted Articulate Storyline on the light wave material.

Keywords: Electronic module, light wave, I-SETS, Articulate Storyline

\section{PENDAHULUAN}

Pendidikan merupakan kebutuhan manusia. Di era digital ini, pendidikan sangatlah diperlukan bagi setiap individu agar tidak tertinggal dengan individu lain. Pendidikan dalam dunia pendidikan berorientasi membekali peserta didik agar dapat memajukan suatu bangsa dan mampu bersaing dengan negara lain [1]. Dalam upaya memajukan bangsa dibutuhkan manusia yang berkualitas dan berkarakter. Bidang pendidikan merupakan salah satu prioritas utama yang dikembangkan sehingga dengan adanya pendidikan yang berkualitas maka akan menunjang sumber daya manusia yang berkualitas pula.

Namun berdasarkan data Programme for International Students Assessment (PISA) yang diterbitkan oleh Organization of Economic Co-operative and Development (OECD) menyatakan bahwa pendidikan Indonesia kategori sains pada 2018 berada di peringkat 71 dari 79 negara, yakni dengan rata-rata skor 396. Nilai ini mengalami penurunan dibanding tes di tahun 2015, di dalam kategori Sains Indonesia berada di peringkat 71 dari 79 negara, yakni dengan rata-rata skor 403 [2]. Penurunan kualitas ini tentu indikasi bahwa rendahnya mutu pendidikan sehingga ada beberapa pekerjaan rumah yang harus dilakukan pemerintahan untuk pembangunan pendidikan.

Dalam rangka meningkatkan mutu pendidikan dasar dan menengah Kementerian Pendidikan dan Kebudayaan melakukan pengembangan Kurikulum Berbasis Kompetensi (KBK) yang telah dilaksanakan sejak tahun 2004 menjadi Kurikulum 2013. Guru diharapkan mampu mengimplementasikan pendidikan karakter, literasi, dan science, technology, engineering and mathematics [3]. Keberhasilan pembelajaran peserta didik dapat diketahui dari beberapa indikator, yaitu aktif dalam pembelajaran, menguasai materi pelajaran, menjawab pertanyaan dengan benar dan mampu mengerjakan soal-soal dengan tepat. Selain itu, bahan belajar, suasana belajar, media, alat peraga dan sumber belajar, serta guru sebagai subyek pembelajaran merupakan peranan penting dalam proses pembelajaran [4].

Bahan ajar sangat mempengaruhi hasil belajar peserta didik [5]. Bahan ajar di sekolah masih menekankan aspek kognitif tanpa disertai adanya penekanan pada aspek afektif dan aplikatif yang mengaitkannya dengan sisi religius, lingkungan, teknologi, dan sosial. Hal ini menyebabkan peserta didik mengalami kesulitan dalam mengaitkan konsep fisika sebagai solusi permasalahan dalam kehidupan sehari-hari [6]. Berdasarkan hasil analisis pendahuluan, 100\% guru dan peserta didik SMAIT/MA menyatakan bahwa peserta didik membutuhkan bahan ajar alternatif dalam proses pembelajaran khususnya pada materi gelombang cahaya.

Sesuai perkembangan jaman bahan ajar dapat diakses melalui internet ataupun dari sumber lain berupa jurnal, artikel, buku elektronik, dan modul elektronik, sehingga memudahkan peserta didik untuk mengakses berbagai materi yang akan dipelajari [7]. Modul pembelajaran elektronik yang terintegrasi dengan animasi, gambar, dan video pembelajaran diharapkan dapat menghadirkan pengalaman nyata peserta didik, sehingga peserta didik dapat terstimulus menggabungkan pengetahuan yang dimiliki peserta didik dengan materi fisika. Berdasarkan hasil penelitian Lisa Tania dan Joni Susilowibowo, bahan ajar modul elektronik sangat baik digunakan dalam upaya meningkatkan keterlibatan peserta didik dalam proses pembelajaran. Pengembangan modul elektronik telah layak digunakan sebagai bahan ajar, namun masih kurang inovatif dan menarik perhatian peserta didik, karena berisi dalam dalam pembelajaran modul elektronik tersebut kurang melibatkan peserta didik menjadi kreatif dan aktif [8]. Berdasarkan hasil analisis pendahuluan, 
$56,25 \%$ guru dan peserta didik SMAIT/MA menyatakan bahwa pembelajaran menggunakan modul elektronik lebih berkualitas dibandingkan pembelajaran tanpa menggunaka modul eletronik.

Articulate Storyline merupakan perangkat lunak yang berfungsi sebagai media presentasi. Perangkat lunak ini memiliki kemampuan teknis dan kemampuan seni, serta kolaborasi kedua kemampuan ini sehingga dapat menghasilkan presentasi yang menarik [9]. Aplikasi ini memiliki smart brainware yang sederhana sehingga memudahkan pengguna pemula dalam menggunakannya. Fungsi-fungsi yang dimiliki aplikasi ini pun menjadikan pengguna lebih efisien dalam menggunakan aplikasi karena tidak perlu menggunakan beberapa aplikasi lainnya dalam membuat bahan ajar. Dalam menekankan aspek kognitif yang disertai adanya penekanan pada aspek afektif dan aplikatif yang mengaitkannya dengan sisi religius, lingkungan, teknologi, dan sosial. Berdasarkan hasil penelitian Rahmah menyatakan bahwa pengembangan bahan ajar berbasis SETS terintegrasi nilainilai Islam efektif untuk meningkatkan hasil belajar peserta didik [10]. Maka model pembelajaran SETS dapat dihubungkan dengan nilai-nilai islam yang terdapat dalam Al Qur'an dan hadist atau disebut pendekatan berbasis I-SETS (Islamic, Science, Environment, Technology, Society). Berdasarkan hasil penelitian Rahmaniati dan Supramono, penggunaan pendekatan I-SETS menjadikan peserta didik lebih mudah memahami materi pelajaran, serta dapat mengambil keputusan akan masalah-masalah yang sedang terjadi dan dapat mengaitkannya ke dalam nilai-nilai islam [11]. Berdasarkan hasil analisis pendahuluan, $68,75 \%$ guru dan peserta didik SMAIT/MA menyatakan bahwa peserta didik antusias saat mengikuti pembelajaran I-SETS pada materi gelombang cahaya. Dan 96,88\% guru dan peserta didik SMAIT/MA menyatakan bahwa modul elektronik lebih menarik jika dilengkapi dengan data dan fenomena dalam kehidupan sehari-hari yang dikaitkan dengan ISETS.

Konsep fisika yang dipelajari peserta didik meliputi hal yang bersifat konkret dan abstrak. Cahaya merupakan gelombang elektromagnetik kepunyaan Allah yang menjadi sumber berjalannya kehidupan alam semesta. Allah berfirman dalam Al Qur'an surat An-Nur ayat 35 yang artinya: "Allah (Pemberi) cahaya (kepada) langit dan bumi. Perumpamaan cahaya Allah, adalah seperti sebuah lubang yang tak tembus, yang di dalatnnya ada pelita besar. Pelita itu di dalam kaca (dan) kaca itu seakan-akan bintang (yang bercahaya) seperti mutiara, yang dinyalakan dengan minyak dari pohon yang banyak berkahnya, (yaitu) pohon zaitun yang tumbuh tidak di sebelah timur (sesuatu) dan tidakpula di sebelah barat(nya) yang minyaknya (saja) hampir-hampir menerangi, walaupun tidak disentuh api. Cahaya di atas cahaya (berlapis-lapis), Allah membimbing kepada cahaya-Nya siapa yang Dia kehendaki, dan Allah memperbuat perumpamaan-perumpamaan bagi manusia, dan Allah Maha Mengetahui segala sesuatu" [12]. Dari ayat tersebut dapat diketahui bahwa cahaya memiliki peran penting dalam kehidupan, Allah lah yang memberikan cahaya kepada alam semesta yang patut kita syukuri dan pelajari lebih detail. Namun berdasarkan hasil penelitian Arshelia bahwa, sebesar $60,6 \%$ peserta didik menganggap bahwa materi gelombang bunyi dan cahaya merupakan satu diantara materi yang dianggap sulit untuk dipahami [13]. Berdasarkan hasil analisis pendahuluan, $68,75 \%$ guru dan peserta didik SMAIT/MA menyatakan bahwa materi gelombang cahaya termasuk materi yang sulit dipahami peserta didik. Tingkat kesulitan pada materi gelombang bunyi dan cahaya terletak pada bagian gelombang cahaya, dikarenakan persamaan matematis dan materi yang dipelajari cukup banyak.

Berdasarkan hasil analisis pendahuluan, 90,63\% guru dan peserta didik SMAIT/MA setuju dengan adanya penelitian pengembangan modul elektronik fisika berbasis I-SETS berbantuan articulate storyline pada materi gelombang cahaya. Uraian di atas menjadikan pijakan dalam melakukan penelitian yang berjudul "Pengembanga Modul Elektronik Fisika Berbasis I-SETS Berbantuan Articulate Storyline Pada Materi Gelombang Cahaya".

\section{METODOLOGI}

Penelitian ini mengunakan metode pengembangan (research and development). Metode pengembangan ( $R$ \& $\mathrm{D}$ ) adalah suatu proses yang digunakan untuk mengembangkan dan mengesahkan produk bidang pendidikan. Langkah-langkah dalam proses ini pada umumnya dikenal sebagai siklus R \& D, yaitu untuk merancang produk dan prosedur baru, yang kemudian diuji secara sistematis, dievaluasi, dan disempurnakan hingga memenuhi kriteria efektivitas, kualitas, atau standar 
tertentu. Produk yang dimaksud tidak hanya berupa benda seperti buku teks, film untuk pembelajaran dan software komputer tetapi dapat juga berupa metode mengajar dan program. Dalam hal ini produk yang akan dikembangkan adalah modul elektronik fisika berbasis i-sets menggunakan aplikasi articulate storyline pada materi gelombang cahaya.

Penelitian ini mengacu pada model pengembangan ADDIE yang terdiri dari beberapa tahapan yakni Analysis (analisis), Design (perencanaan), Development (pengembangan), Implementation (penerapan), Evaluation (evaluasi). Model ADDIE merupakan model pengembangan media yang tersusun secara sistematis, seperti gambar berikut [14]:

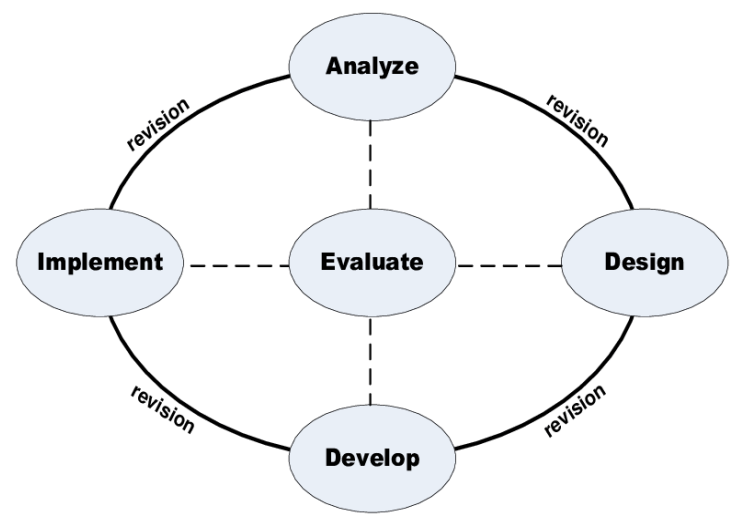

GAMBAR 1. Prosedur Pengembangan Model ADDIE (Prawiradilaga,2012)

Teknik pengumpulan data dalam penelitian pengembangan modul elektronik ini menggunakan tiga jenis, yaitu wawancara, dokumentasi dan kuesioner (angket). Wawancara yang dilakukan untuk mengetahui data awal dalam penelitian dan informasi yang diperoleh digunakan sebagai masukan untuk mengembangkan bahan ajar modul elektronik dengan menggunakan aplikasi articulate storyline. Pada saat penerapan modul elektronik dengan menggunakan aplikasi articulate storyline peneliti mengumpulkan dokumentasi data-data tentang keadaan peserta didik. Angket digunakan pada saat pengembangan, penerapan dan evaluasi. Pengembangan modul elektronik dengan menggunakan aplikasi articulate storyline dilakukan oleh validator ahli materi, dan validator ahli media. Pada penerapan dilakukakan uji coba modul elektronik dengan menggunakan aplikasi articulate storyline dengan memberikan angket kepada peserta didik dan guru. Sedangkan evaluasi modul elektronik dengan menggunakan aplikasi articulate storyline dilakukan untuk mengetahui respon guru dan peserta didik terhadap kelayakan modul elektronik fisika berbasis I-SETS menggunakan aplikasi Articulate Storyline pada materi gelombang cahaya.

Teknik analisis data pada penelitian ini menggunakan teknik analisis deskriptif kualitatif yang memaparkan hasil pengembangan produk yang berupa modul elektronik dengan menggunakan aplikasi articulate storyline. Data kuantitatif yang diperoleh saat uji coba kepada responden melalui angket dengan skala likert, dianalisis secara statistif deskriptif kualitatif dengan langkah-langkah (a) pengumpulan data kasar: (b) pemberian skor untuk statistik kuantitatif: (c) skor yang diperoleh dikonversikan menjadi nilai dengan skala lima.

Pada skala likert, variabel yang diukur dijabarkan menjadi indikator variabel. Kemudian indikator tersebut dijadikan titik tolak untuk menyusun butir-butir instrumen yang dapat berupa pertanyaan atau pernyataan [15]. 
TABEL 1. Aturan Pemberian Skor (Sugiyono, 2012)

\begin{tabular}{cc}
\hline Kategori & Bobot Skor \\
\hline Sangat Baik/Sangat Sesuai/Sangat Setuju & 5 \\
Baik/Sesuai/Setuju & 4 \\
Cukup Baik/Cukup Sesuai/Cukup Setuju & 3 \\
Kurang Baik/Kurang Sesuai/Kurang Setuju & 2 \\
Sangat Tidak Baik/Sangat Tidak Sesuai/Sangat Tidak Setuju & 1 \\
\hline
\end{tabular}

Data tersebut kemudian dianalisis untuk mengetahui kualitas modul elektronik fisika berbasis ISETS berbantuan articulate storyline dengan langkah sebagai berikut :

a. Menghitung skor rata-rata dari setiap aspek yang dinilai dengan persamaan:

Keterangan:

$$
\bar{X}=\frac{\sum X}{N}
$$

$\bar{X} \quad=$ Skor rata-rata penilaian oleh pengguna

$\sum X=$ Jumlah skor yang diperoleh pengguna

$\mathrm{N}=$ Jumlah butir pertanyaan

b. Mengubah skor rata-rata yang diperoleh menjadi data kualitatif

Kategori kualitatif ditentukan terlebih dahulu dengan mencari interval jarak antara jenjang kategori sangat setuju (SS) hingga tidak setuju (TS) dengan menggunakan persamaan berikut [16]:

$$
\begin{aligned}
\text { Jarak interval }(i)=\frac{\text { skor tertinggi }- \text { skor terendah }}{\text { jumlah kelas interval }} \\
=\frac{5-1}{5} \\
=0,8
\end{aligned}
$$

Sehingga diperoleh kategori penilaian modul elektronik fisika berbasis I-SETS sebagaimana ditampilkan dalam tabel berikut :

TABEL 2. Interval Kelas (Akbar, S. D., 2013)

\begin{tabular}{ll}
\hline \multicolumn{1}{c}{ Skor Rata-Rata $(\bar{X})$} & \multicolumn{1}{c}{ Kategori } \\
\hline $4,20<(\bar{X}) \leq 5,000$ & Sangat baik atau Sangat sesuai \\
$3,40<(\bar{X}) \leq 4,20$ & Baik atau Sesuai \\
$2,60<(\bar{X}) \leq 3,40$ & Cukup \\
$1,80<(\bar{X}) \leq 2,60$ & Kurang Baik atau Kurang Sesuai \\
$1,00<(\bar{X}) \leq 1,80$ & Sangat tidak baik atau Sangat Tidak Sesuai \\
\hline
\end{tabular}

c. Menghitung persentase kelayakan dengan persamaan sebagai berikut:

$$
\text { Presentase kelayakan }=\frac{\text { skor hasil penelitian }}{\text { skor maksimal ideal }} \times 100 \%
$$

Kriteria validasi modul elektronik fisika berbasis I-SETS ditampilkan dalam tabel berikut [17]:

TABEL 3. Kriteria validasi kelayakan modul (Akbar, S. D., 2013)

\begin{tabular}{ll}
\hline \multicolumn{1}{c}{ Kriteria Validasi } & \multicolumn{1}{c}{ Tingkat Validitas } \\
\hline $85,01 \%-100,00 \%$ & Sangat Valid atau dapat digunakan tanpa revisi \\
$70,01 \%-85,00 \%$ & Cukup Valid atau dapat digunakan namun perlu direvisi \\
& kecil \\
$50,01 \%-70,00 \%$ & Kurang valid, disarankan tidak dipergunakan karena perlu \\
& revisi besar \\
$01,00 \%-50,00 \%$ & Tidak valid atau tidak boleh dipergunakan \\
\hline
\end{tabular}




\section{HASIL DAN PEMBAHASAN}

Pada penelitian ini yang digunakan hanya menggunakan angket, karena peneliti hanya memberikan perlakuan yang sama terhadap objek yang akan di teliti. Tujuan penelitian ini adalah mengembangkan produk berupa modul elektronik fisika berbasis I-SETS menggunakan aplikasi Articulate Storyline pada materi gelombang cahaya, dan mengetahui respon guru dan peserta didik terhadap kelayakan modul elektronik fisika berbasis I-SETS menggunakan aplikasi Articulate Storyline pada materi gelombang cahaya.

Desain modul elektronik menggunakan format yang dikemukakan oleh Prastowo (2011) dengan beberapa modifikasi[18]. Berikut format modul elektronik yang dikembangkan:

1. Bagian awal:

1.1. Cover

1.2. Kata pengantar

1.3. Menu

1.4. Standar kompetensi

1.4.1. Kompetensi inti

1.4.2. Indikator pencapaian kompetensi

1.4.3. Tujuan pembelajaran

2. Bagian isi:

1.1. Judul materi

1.2. Uraian materi

1.3. Latihan

3. Bagian akhir:

1.1. Evaluasi

1.2. Daftar pustaka

1.3. Identitas pembuat

Penelitian ini masih pada tahap pengembangan. Setelah peneliti membuat analisis kebutuhan, membuat desain modul elektronik fisika, peneliti mulai ke tahap pengembangan. Berikut tampilan awal media seperti pada gambar berikut:

1. Tampilan Cover

Tampilan cover merupakan tampilan awal dari modul elektronik. Pada tampilan ini, peserta didik diminta untuk mengisi nama dan kelasnya.

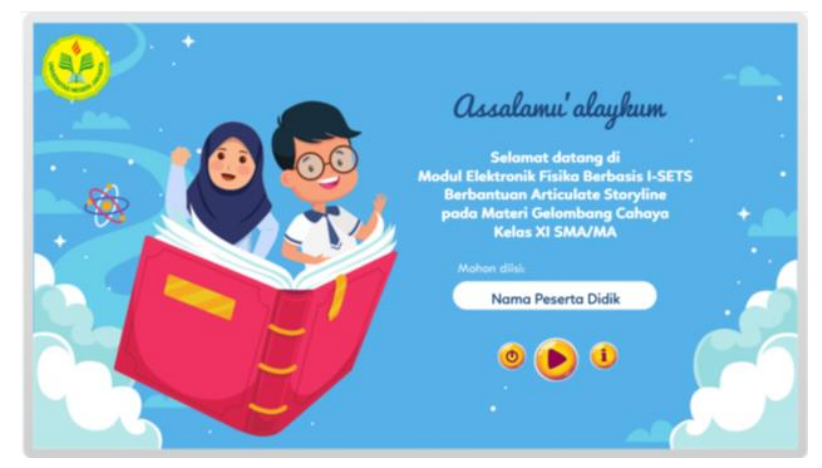

GAMBAR 2. Tampilan Cover pada Modul Elektronik

2. Tampilan Kata Pengantar

Tampilan kata pengantar merupakan tampilan awal dari modul elektronik. Pada tampilan ini, diperkenalkan ikon guru dan peserta didik diajak untuk berdo'a sebelum belajar. 


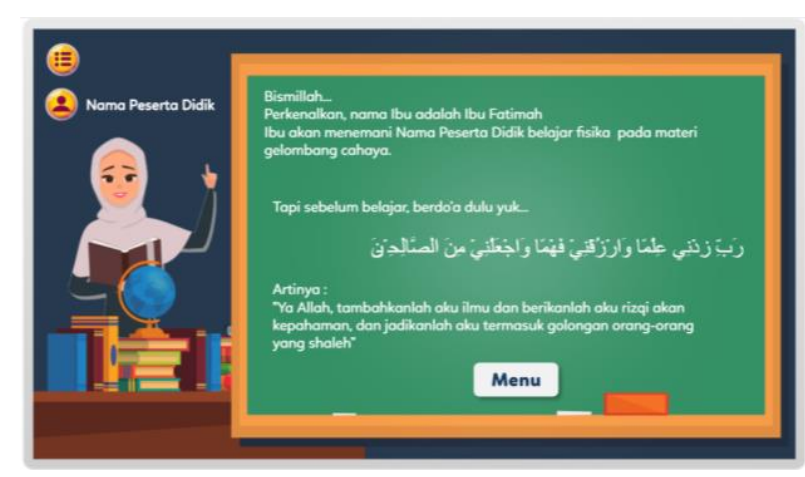

GAMBAR 3. Tampilan Kata Pengantar pada Modul Elektronik

3. Tampilan Menu

Tampilan menu merupakan tampilan awal dari modul elektronik. Pada tampilan ini, ditampilkan рор up menu utama modul elektronik.

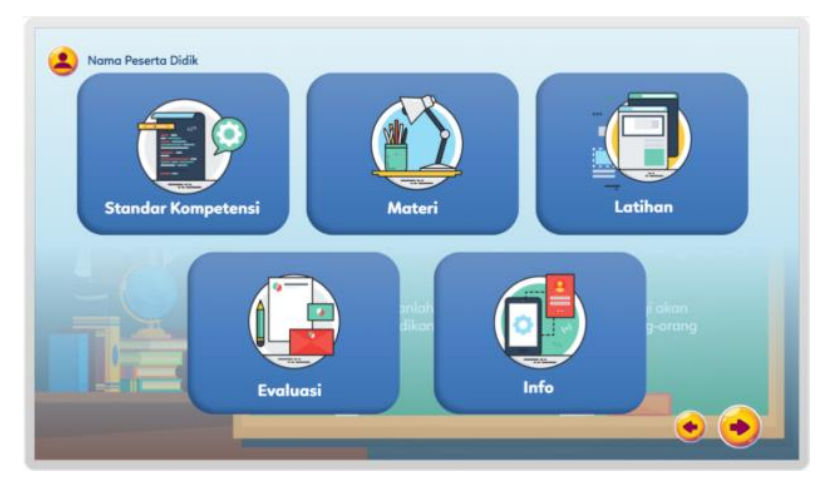

GAMBAR 4. Tampilan Menu pada Modul Elektronik

4. Tampilan Judul Materi

Tampilan judul materi merupakan tampilan isi dari modul elektronik. Pada tampilan ini, ditampilkan materi gelombang cahaya yang dibahas pada modul elektronik.

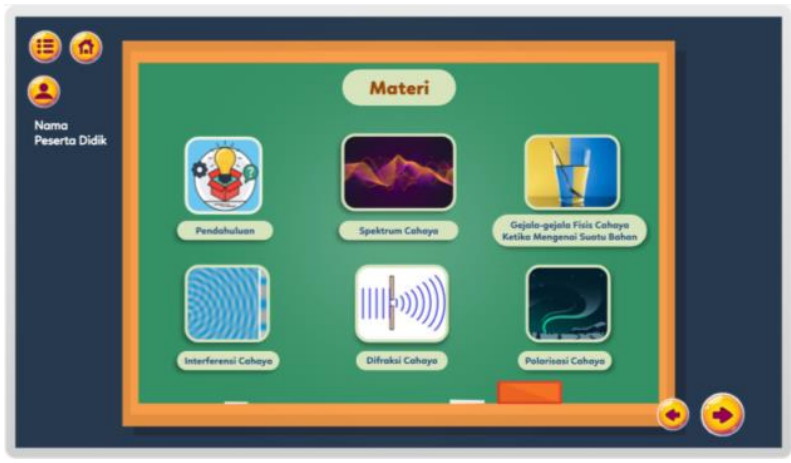

GAMBAR 5. Tampilan Judul Materi pada Modul Elektronik

5. Tampilan Info

Tampilan info merupakan tampilan akhir dari modul elektronik. Pada tampilan ini, ditampilan petunjuk tombol untuk memahami peserta didik akan tombol yang berada pada modul elektronik, daftar pustaka yang digunakan peneliti dalam mengembangkan modul elektronik, dan identitas pembuat. 


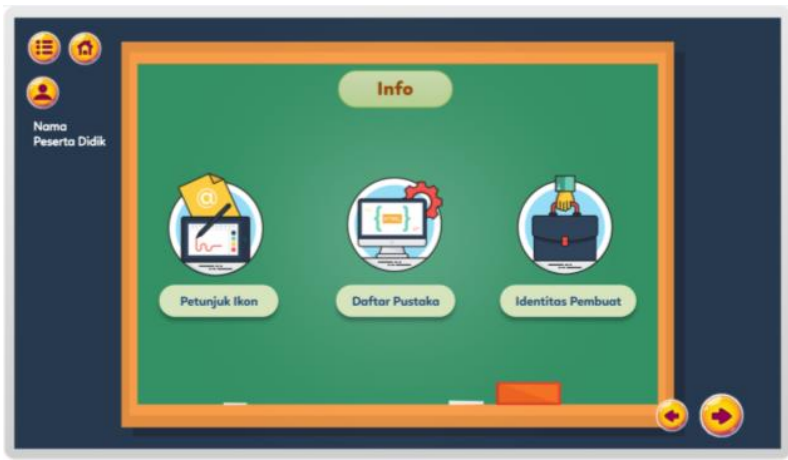

GAMBAR 6. Tampilan Info pada Modul Elektronik

Pada umumnya pembuatan modul elektronik menggunakan software 3D PageFlip Professional [19]. Tetapi pada penelitian kali ini modul elektronik dikembangkan dengan menggunakan software articulate storyline. Sumber referensi mengacu pada kompetensi inti, kompetensi dasar, standar kompetensi, indikator pencapaian kompetensi, tujuan pembelajaran sesuai dengan kurikulum 2013. Acuan ini juga akan digunakan jika mengembangan media berupa e-learning [20]. Selain dengan membuat modul elektronik, media yang dapat digunakan untuk mempelajari materi gelombang dapat berupa Augmented Reality [21] dan Aplikasi Android berbasis web [22]. Adapun pembelajaran gelombang nantinya dikelas dapat mengacu pada STEM [23].

Peneliti menyusun Garis-Garis Besar Isi Modul (GBIM) sebagai pedoman dalam penyusunan modul dalam Microsoft Word, kemudian menyiapkan outline/rancangan modul berupa penentuan topik yang akan dimuat, mengatur urutan topik dan mempersiapkan outline. Outline disusun dan dikembangkan menggunakan Articulate Storyline. Secara umum cara pengembangan yang dilakukan sama dengan pengembangan e-modul menggunakan 3D [19].

Sebelum media diterapkan langsung dalam pembelajaran terlebih dahulu dilakukan validasi yaitu proses kegiatan untuk menilai apakah rancangan produk, dalam hal ini bahan ajar berbentuk modul elektronik sebagai penunjang pembelajaran fisika akan lebih menarik dari bahan ajar sebelumnya. Setelah peneliti selesai membuat media, selanjutnya media diujicobakan dalam kegiatan pembelajaran. Penerapan ini dimaksudkan untuk mendapatkan informasi mengenai modul elektronik yang dikembangkan. Penerapan dilakukan untuk mengetahui kelayakan modul elektronik dengan menggunakan aplikasi Articulate Storyline. Dari hasil penerapan, dilakukan evaluasi media bertujuan untuk mengetahui bagaimana respon guru dan peserta didik terhadap modul elektronik fisika berbasis I-SETS menggunakan aplikasi Articulate Storyline pada materi gelombang cahaya. Penelitian ini belum membahas bagaimana pengaruh penggunaan media yang dikembangkan terhadap hasil belajar siswa, seperti yang telah dilakukan pada penelitian lain [24].

\section{SIMPULAN}

Penelitian ini menggunakan model pengembangan ADDIE, dimana penelitian masih dalam tahap (development) pengembangan modul elektronik fisika berbasis I-SETS menggunakan software articulate storyline. Peneliti sedang melakukan validasi ke ahli media, dan ahli materi yang tahap selanjutnya akan melakukan uji coba ke guru, dan peserta didik.

\section{UCAPAN TERIMAKASIH}

Peneliti mengucapkan terimakasih kepada Bapak Dr. Esmar, M.T selaku Ketua Prodi Pendidikan Fisika, Universitas Negeri Jakarta, beserta dosen-dosen di program studi Pendidikan Fisika yang telah memberikan bimbingan serta masukan dalam menyelesaikan penelitian pengembangan ini. 


\section{REFERENSI}

[1] M. Munirah, "Sistem Pendidikan Di Indonesia: antara Keinginan dan Realita," AULADUNA: Jurnal Pendidikan Dasar Islam, vol. 2, no. 2, pp. 233-245, 2015.

[2] OECCD, "PISA 2018: Insights and Interpretations," PISA: OECD Publishing, 2019.

[3] Kemendikbud, "Program Kerja Direktorat Pembinaan SMA TAHUN 2019," Jakarta: Direktorat Pembinaan Sekolah Menengah Atas Direktorat Jenderal Pendidikan Dasar dan Menengah Kementerian Pendidikan dan Kebudayaan, pp. 79-80, 2019.

[4] M. Gulo, "Meningkatkan Hasil Belajar Fisika dengan Menggunakan Alat Peraga Sederhana pada Materi Gerak Melingkar di Kelas X-5 SMA Negeri 3 Gunungsitoli Semester Ganjil Tahun Pelajaran 2014/2015," Wahana Inovasi, vol. 6, no. 1, pp. 1-14, 2018.

[5] V. L. P. Sutrisno, B. T. Anto, "Faktor-Faktor yang Mempengaruhi Hasil Belajar Peserta Didik pada Pembelajaran Praktik Kelistrikan Otomotif SMK di Kota Yogyakarta," Jurnal Pendidikan Vokasi, vol. 6, no. 1, pp. 111-120, 2016.

[6] A. I. Wahyuni, "Pengembangan Bahan Ajar Fisika Berbasis I-SETS (Islamic, Science, Environment, Technology, Society) Terintegrasi Karakter Materi Hukum Pascal dan Archimedes," Doctoral dissertation, Universitas Negeri Semarang, 2017.

[7] R. Ardiansyah, A. D. Corebima and F. Rohman, "Analisis Kebutuhan Pengembangan Bahan Ajar Perubahan Materi Genetik pada Matakuliah Genetika di Universitas Negeri Malang," Seminar Nasional Pendidikan dan Saintek Universitas Muhammadiyah Surakarta, pp. 749752, 2016.

[8] L. Tania, "Pengembangan Bahan Ajar Modul elektronik sebagai Pendukung Pembelajaran Kurikulum 2013 pada Materi Ayat Jurnal Penyesuaian Perusahaan Jasa Peserta Didik Kelas X Akuntansi SMK Negeri 1 Surabaya," Jurnal Pendidikan Akuntansi (JPAK), vol. 5, no. 2, 2017.

[9] N. Kholifah and A. B. Santosa, "Pengembangan Media Pembelajaran Menggunakan Software Articulate pada Mata Pelajaran Elektronika Dasar Kelas X Tav Di SMK Negeri 1 Madiun," Jurnal Pendidikan Teknik Elektro, vol. 5, no. 1, 2016.

[10] S. Z. Rahmah, S. Mulyani \& M. Masyikuri, "Pengembangan Modul Berbasis SETS (Science, Environment, Technology, Society) Terintegrasi Nilai Islam di SMAI Surabaya pada Materi Ikatan Kimia," Jurnal Pendidikan, vol. 1, no. 2, pp. 57-62, 2017.

[11] R. Rahmaniati and S. Supramono, "Pembelajaran I-SETS (Islamic, Science, Environment, Technology and Society) terhadap Hasil Belajar Peserta didik," Anterior Jurnal, vol. 14, no. 2, pp. 194-200, 2015.

[12] Departemen Agama Republik Indonesia, "Al-Quran Cordoba," Bandung: PT. Cordoba Internasional Indonesia, 2012.

[13] T. N. Arshelia, "Pengembangan Modul Elektronik 3D pada Konsep Gelombang Bunyi dan Cahaya Untuk Peserta Didik SMA," Bachelor's Thesis, Fakultas Ilmu Tarbiyah dan Keguruan, 2017.

[14] Prawiradilaga, "Wawasan Teknologi Pendidikan," Jakarta: Kencana Prenada Media Group, 2012.

[15] Sugiyono, "Metode Penelitian Pendidikan Pendekatan Kualitatif, Kuantitatif, dan R \& D," Bandung: Alfabeta, 2012.

[16] S. D. Akbar, “Instrumen Perangkat Pembelajaran,” Bandung: PT. Remaja Rosdaarya, 2013.

[17] S. D. Akbar, "Instrumen Perangkat Pembelajaran," Bandung: PT. Remaja Rosdaarya, 2013. 
[18] A. Prastowo, "Metode penelitian kualitatif dalam perspektif rancangan penelitian," Jogjakarta: Ar-Ruzz Media, 2011.

[19] F. Bakri, B. Z. Siahaan, and A. H. Permana, "Rancangan Website Pembelajaran Terintegrasi dengan Modul Digital Fisika Menggunakan 3D PageFlip Professional", JPPPF (Jurnal Penelitian dan Pengembangan Pendidikan Fisika), vol. 2, no. 2, pp. 113 - 118, 2016.

[20] I. A. Putri, S. Siswoyo, and W. Indrasari, "Pengembangan Media Pembelajaran Fisika Menggunakan Lectora Inspire pada Materi Usaha dan Energi SMA", JPPPF (Jurnal Penelitian dan Pengembangan Pendidikan Fisika), vol. 2, no. 2, pp. 71 - 78, 2016.

[21] D. Ambarwulan and D. Muliyati, "The Design of Augmented Reality Application as Learning Media Marker-Based for Android Smartphone", JPPPF (Jurnal Penelitian dan Pengembangan Pendidikan Fisika), vol. 2, no. 1, pp. 73 - 80, 2016.

[22] B. R. Simanjuntak, D. Desnita, and E. Budi, "The Development of Web-based Instructional Media for Teaching Wave Physics on Android Mobile", JPPPF (Jurnal Penelitian dan Pengembangan Pendidikan Fisika), vol. 4, no. 1, pp. 1 - 10, 2018.

[23] R. Afifah and E. Ellianawati, "Student Cognitive Profile with STEM Based Teaching Material on the Subject of Vibrations and Waves", JPPPF (Jurnal Penelitian dan Pengembangan Pendidikan Fisika), vol. 5, no. 2, pp. 217 - 226, 2019.

[24] P. Sinulingga, T. J. Hartanto, and B. Santoso, "Implementasi Pembelajaran Fisika Berbantuan Media Simulasi PhET untuk Meningkatkan Hasil Belajar Siswa Pada Materi Listrik Dinamis", JPPPF (Jurnal Penelitian dan Pengembangan Pendidikan Fisika), vol. 2, no. 1 , pp. $57-64,2016$. 